\title{
SPONTANEOUS BACTERIAL EMPYEMA IN CIRRHOTIC PATIENTS:CLINICAL FEATURES AND OUTCOMES
}

\author{
Ahmed Awad Abd El Khalek, Resident in Tropical Medicine and Gastroenterology \\ Department. \\ Dr. Safaa Khalaf Abd Allah, Lecturer of Tropical Medicine and Gastroenterology. \\ Dr. Khairy Hammam Morsy, assistant professor of Tropical Medicine and \\ Gastroenterology. \\ Sohag University Hospital , Egypt, 2017.
}

\begin{abstract}
AIM: The aim of this study is to determine the prevalence of spontaneous bacterial empyema among patients with liver cirrhosis and identify clinical features and outcomes of spontaneous bacterial empyema.

PATIENTS AND METHODS : The study included 800 patients (males and females) presented with liver cirrhosis with and without ascites and pleural effusion. A total of 100 (57 males and 43 females) patients with liver cirrhosis and hepatic hydrothorax, (99 patients) with and (1 patients) without ascites were enrolled. Spontaneous bacterial empyema was diagnosed by a pleural fluid PMNL count $>500$ cells $/ \mathrm{mm} 3$ without radiographic evidence of pneumonia or a contiguous infection process on chest radiography.

RESULTS: the frequency of spontaneous bacterial empyema among cirrhotic patients with hepatic hydrothorax was 19\% (19 out of 100 cirrhotic patients).

CONCLUSION: SBEM was recognized in $19 \%$ of cirrhotic patients with ascites and hepatic hydrothorax. So, it is a frequent but underdiagnosed complication of hepatic hydrothorax and has a poor prognosis.
\end{abstract}

Key words: Spontaneous bacterial empyema; cirrhosis; hydrothorax

\section{INTRODUCTION}

Inspite of the advancement in medical care for patients with advanced liver cirrhosis, bacterial infections remain very common and account for significant morbidity and mortality (approximately $30 \%)$ in these patients ${ }^{[1,2]}$

Spontaneous bacterial empyema (SBEM) is the infection of a pre-existing hydrothorax in which pneumonia has been excluded. SBEM has been found in $10 \%-20 \%$ of hospitalized patients with hepatic hydrothorax ${ }^{[3-5]}$. SBEM can occur either with SBP, through transdiaphragmatic spread, or without SBP through hematogenous spread ${ }^{[6]}$. factors that contribute to development of SBEM in patients with cirrhosis are presence of SBP, low pleural fluid protein and complement (C3) levels, low serum albumin and advanced liver disease ${ }^{[4,7]}$.

Any patient with hydrothorax who develops fever, unexplained deterioration in renal function, pleuritic pain or encephalopathy should undergo thoracocentesis, as SBEM is suspected, particularly in those with non-infected $\operatorname{ascites}^{[8]}$.

Hospital mortality has been reported as $20 \%-40 \%$ in cirrhotic patients with $\mathrm{SBEM}^{[3,5]}$. So, treatment with an 
intravenous third generation cephalosporin antibiotic such as first line therapy: cefotaxime $2 \mathrm{gm} / 12 \mathrm{~h}$ IV or ceftriaxone $1 \mathrm{gm} / 12-24 \mathrm{IV}$ for $7-10$ days should be initiated immediately when pleural fluid PMN $>250$ cells $/ \mathrm{mm}^{3}$ while awaiting culture result ${ }^{[9,6]}$. Chest Tube drainage is contraindicated in patients with hepatic hydrothorax and SBEM because of the risk of life threatening fluid depletion, protein loss and electrolyte imbalance ${ }^{[10,3]}$.

\section{AIM OF THE WORK}

The aim of this study is to determine the prevalence of spontaneous bacterial empyema among patients with liver cirrhosis and identify clinical features and outcomes of spontaneous bacterial empyema.

\section{PATIENTS AND METHODS}

The study included 800 patients presented with liver cirrhosis with and without ascites and pleural effusion . A total of 100 (57 males and 43 females) patients with liver cirrhosis and hepatic hydrothorax, (99 patients) with and (1 patients) without ascites were enrolled.. The severity of the liver disease was assessed according to the Child-Pugh classification.

Patients with evidence of pneumonia or pleural effusion due to cardiac and pulmonary diseases before the infections episode were excluded from the study.

All patients were subjected to:

\section{1- history taking;}

2- full clinical examination

3- Imaging study: I. Abdominal Ultrasound: The abdominal ultrasonography was used to asses liver size, shape and texture, focal lesion and portal vein diameter. Also to assess the size of spleen in addition to detection of ascites and pleural effusion; II. Chest X-ray: Chest radiography, post-anterior and lateral view for the effusion and to exclude pneumonia.

4- Laboratory investigations: AComplete blood picture; B- Liver function tests; C-Renal function test; DViral markers: Hepatitis B surface antigen (HBs $\mathrm{Ag}$ ), and Hepatitis $\mathrm{C}$ virus $\mathrm{Ab}(\mathrm{HCV} \mathrm{Ab})$ using third generation ELISA test.

5- Diagnostic thoracocentesis: The pleural fluid is collected under aseptic conditions in a sterile container and sent, as soon as possible, to the laboratory and processed for the measurement of $\mathrm{pH}$, glucose, protein, albumin, leukocyte count and differential.

Spontaneous bacterial empyema was diagnosed by positive pleural fluid culture or, if negative, a pleural fluid PMNL count $>500$ cells $/ \mathrm{mm} 3$ without radiographic evidence of pneumonia or a contiguous infection process on chest radiography.

6- Paracentesis of the ascitic fluid: The ascitic fluid is collected at the same time and processed in the same way as the pleural fluid.

The diagnosis of spontaneous bacterial peritonitis was established by an ascitic fluid PMNL count $>250$ cells $/ \mathrm{mm}^{3}$, with an absence of findings suggesting secondary peritonitis.

\section{Ethical aspects}

This study was approved by the Ethical Committee of sohag University, and a written informed consent was obtained from all enrolled participants.

\section{Statistical analysis}

Statistical analysis was performed using SPSS, version 17. All data were expressed as mean $\pm \mathrm{SD}$ or frequencies. For statistical evaluation, Student's t test was used. Significance was accepted at $\mathrm{p}<$ 0.05 level. 


\section{RESULTS}

During the period of study from July 2016 to May 2017, 800 cirrhotic patients were consecutively admitted to the Department of Tropical Medicine and Gastroenterology, sohag University Hospital . Among these 800 patients, 100 (12.5\%) had detectable pleural effusion. The site of pleural effusion was detected by chest X-ray and chest US. It was right sided in $85(85 \%)$ cases, left sided in $10(10 \%)$ cases, and bilateral in five $(5 \%)$ cases. Ninteen cases met the criteria of SBEM, and the remaining 81 were considered as sterile pleural effusion. The demographic and clinical data of all patients with SBEM and sterile pleural effusion are compared as shown in Table 1 . The commonest presenting symptoms and signs in patients with SBEM were fever (94.74\%), dyspnea and couph $(89.47 \%$ for each), followed by encephalopathy $(68.42 \%)$ and abdominal pain (52.63\%). Patients with SBEM had a significantly higher frequency of fever ( $<<0.0001)$, abdominal pain $(\mathrm{p}=0.003)$, encephalopathy $(\mathrm{p}<0.0001)$, and hypotension $(\mathrm{p}=0.01)$ than those with sterile hydrothorax.

Table $(2,3)$ showed laboratory data of all patients with SBEM in comparison with sterile pleural effusion. There is no significant statistical difference between patients with SBEM and patients with sterile pleural effusion as regard ( complete blood count, liver enzymes, serum albumin , bilirubin and prothrombin time)

Patients with SBEM had a significantly higher polymorphonuclear (PMN) cell count in pleural fluid $(p<0.0001)$, lower pleural fluid glucose level $(p<0.0001)$, lower pleural fluid $\mathrm{pH}(\mathrm{p}<0.0001)$, and no significant statistical difference as regard pleural fluid protein.

There was no significant statistical difference between SBEM and uncomplicated hydrothorax as regard the distribution of pleural effusion as shown in Table 4.

There was no significant statistical difference between SBEM and uncomplicated hydrothorax as regard abdominal or chest sonographic examination, and patients with SBEM had a significantly higher rate of associated SBP than those with sterile hydrothorax as shown in Table 5.

All 19 cases with SBEM received third-generation cephalosporin (cefotaxime $2 \mathrm{~g} / 12 \mathrm{~h}$ for 7-10 days); only $8(42.11 \%)$ patients needed repeated aspiration in addition to cefotaxime to relieve dyspnea from massive effusion and no cases needed intercostal tube insertion. The mortality rate of cirrhotic patients with SBEM during treatment was $21 \%$ (4 of 19). 
Table (1): Comparison between SBEM and sterile pleural effusion as regard clinical

\begin{tabular}{|c|c|c|c|}
\hline Variable & $\begin{array}{l}\text { SBEM } \\
(\mathrm{N}=19)\end{array}$ & $\begin{array}{l}\text { Sterile pleural effusion } \\
\qquad(\mathrm{N}=\mathbf{8 1})\end{array}$ & $P$ value \\
\hline $\begin{array}{l}\text { Encephalopathy } \\
\text { No } \\
\text { Grade } 1 \\
\text { Grade } 3\end{array}$ & $\begin{array}{c}6(31.58 \%) \\
12(63.16 \%) \\
1(5.26 \%)\end{array}$ & $\begin{array}{c}68(83.95 \%) \\
13(16.05 \%) \\
0\end{array}$ & $<0.0001$ \\
\hline $\begin{array}{l}\text { Abdominal pain } \\
\text { No } \\
\text { Yes }\end{array}$ & $\begin{array}{c}9(47.37 \%) \\
10(52.63 \%)\end{array}$ & $\begin{array}{l}65(80.25 \%) \\
16(19.75 \%)\end{array}$ & 0.003 \\
\hline $\begin{array}{l}\text { Cough } \\
\text { No } \\
\text { Yes }\end{array}$ & $\begin{array}{c}2(10.53 \%) \\
17(89.47 \%)\end{array}$ & $\begin{array}{l}21(25.93 \%) \\
60(74.07 \%)\end{array}$ & 0.23 \\
\hline $\begin{array}{l}\text { Dyspnea } \\
\text { No } \\
\text { Yes } \\
\end{array}$ & $\begin{array}{c}2(10.53 \%) \\
17(89.47 \%)\end{array}$ & $\begin{array}{l}12(14.81 \%) \\
69(85.19 \%)\end{array}$ & 1.00 \\
\hline $\begin{array}{l}\text { Chest pain } \\
\text { No } \\
\text { Yes }\end{array}$ & $\begin{array}{c}12(63.16 \%) \\
7(36.84 \%)\end{array}$ & $\begin{array}{l}58(71.60 \%) \\
23(28.40 \%)\end{array}$ & 0.47 \\
\hline $\begin{array}{l}\text { Hypotension } \\
\text { No } \\
\text { Yes }\end{array}$ & $\begin{array}{c}15(78.95 \%) \\
4(21.05 \%)\end{array}$ & $\begin{array}{c}79(97.53 \%) \\
2(2.47 \%)\end{array}$ & 0.01 \\
\hline $\begin{array}{l}\text { Fever } \\
\text { No } \\
\text { Low grade } \\
\text { High grade }\end{array}$ & $\begin{array}{c}1(5.26 \%) \\
16(84.21 \%) \\
2(10.53 \%)\end{array}$ & $\begin{array}{c}67(82.72 \%) \\
13(16.05 \%) \\
1(1.23 \%)\end{array}$ & $<0.0001$ \\
\hline $\begin{array}{l}\text { HCC presence } \\
\text { No } \\
\text { Yes }\end{array}$ & $\begin{array}{c}15(78.95 \%) \\
4(21.05 \%)\end{array}$ & $\begin{array}{c}72(88.89 \%) \\
9(11.11 \%)\end{array}$ & 0.26 \\
\hline
\end{tabular}


Table (2): Laboratory findings in patients with SBEM and uncomplicated hydrothorax

\begin{tabular}{|c|c|c|c|}
\hline Variable & $\begin{array}{l}\text { SBEM } \\
(\mathrm{N}=19)\end{array}$ & $\begin{array}{c}\text { uncomplicated } \\
\text { hydrothorax }(N=81)\end{array}$ & P-value \\
\hline CBC & & & \\
\hline $\begin{array}{l}\text { HB level: } \\
\text { Normal } \\
\text { Reduced }\end{array}$ & $\begin{array}{l}5(26.3 \%) \\
14(73.6 \%)\end{array}$ & $\begin{array}{l}25(30.8 \%) \\
56(69.1 \%)\end{array}$ & $\begin{array}{l}\text { 0.70 } \\
(\mathbf{N S})\end{array}$ \\
\hline $\begin{array}{l}\text { WBCS count : } \\
\text { Normal } \\
\text { Raised }\end{array}$ & $\begin{array}{l}11(57.8 \%) \\
8(42.2 \%)\end{array}$ & $\begin{array}{l}48(59.2 \%) \\
33(40.7 \%)\end{array}$ & $\begin{array}{l}0.91 \\
(\mathrm{NS})\end{array}$ \\
\hline $\begin{array}{l}\text { Platelets count: } \\
\text { Normal } \\
\text { Low }\end{array}$ & $\begin{array}{c}3(15.7 \%) \\
16(84.2 \%)\end{array}$ & $\begin{array}{l}11(13.5 \%) \\
70(86.5 \%)\end{array}$ & $\begin{array}{l}\mathbf{0 . 7 3} \\
(\mathrm{NS})\end{array}$ \\
\hline Liver functions & & & \\
\hline $\begin{array}{l}\text { ALT: } \\
\text { Normal }\end{array}$ & $10(52.6 \%)$ & $43(53 \%)$ & \\
\hline Raised up to 2.5 folds & $7(36.8 \%)$ & $33(40.7 \%)$ & $\begin{array}{l}\text { 0.79 } \\
(\mathbf{N S})\end{array}$ \\
\hline Raised $>2.5$ folds & $2(10.6 \%)$ & $5(6.3 \%)$ & \\
\hline $\begin{array}{l}\text { AST: } \\
\text { Normal } \\
\text { Raised up to } 2.5 \text { folds } \\
\text { Raised }>2.5 \text { folds }\end{array}$ & $\begin{array}{c}9(47.3 \%) \\
7(36.8 \%) \\
3(15.9 \%)\end{array}$ & $\begin{array}{l}32(39.5 \%) \\
38(46.9 \%) \\
11(13.5 \%)\end{array}$ & $\begin{array}{l}0.73 \\
(\mathbf{N S})\end{array}$ \\
\hline $\begin{array}{l}\text { Serum albumin: } \\
\text { Normal } \\
\text { Reduced } \\
\end{array}$ & $\begin{array}{c}1(5.3 \%) \\
18(94.7 \%)\end{array}$ & $\begin{array}{c}3(3.7 \%) \\
78(96.2 \%)\end{array}$ & $\begin{array}{l}\mathbf{0 . 5 8} \\
(\mathrm{NS})\end{array}$ \\
\hline $\begin{array}{l}\text { Serum bilirubin: } \\
\text { Normal } \\
\text { Raised }\end{array}$ & $\begin{array}{c}6(31.5 \%) \\
13(68.4 \%)\end{array}$ & $\begin{array}{l}24(29.6 \%) \\
57(70.3 \%)\end{array}$ & $\begin{array}{l}\mathbf{0 . 8 7} \\
(\mathbf{N S})\end{array}$ \\
\hline $\begin{array}{l}\text { Prothrombin time: } \\
\text { Normal (up to } 15 \mathrm{sec} \text { ) } \\
\text { Prolonged ( >15 sec) } \\
\text { (>3second than control) }\end{array}$ & $\begin{array}{r}4(21.1 \%) \\
15(78.9 \%)\end{array}$ & $\begin{array}{c}17(20.9 \%) \\
64(79 \%)\end{array}$ & $\begin{array}{l}\text { 1.00 } \\
\text { (NS) }\end{array}$ \\
\hline
\end{tabular}


Table (3): Pleural fluid study of patients with SBEM in comparison with uncomplicated hydrothorax

\begin{tabular}{|c|c|c|c|}
\hline Pleural Fluid Study & $\begin{array}{l}\text { SBEM } \\
(\mathbf{N}=19)\end{array}$ & $\begin{array}{c}\text { uncomplicated } \\
\text { hydrothorax }(\mathrm{N}=81) \\
\text { accessible }=69\end{array}$ & P-value \\
\hline $\begin{array}{l}\text { PH: } \\
<7.59 \\
>7.6\end{array}$ & $\begin{array}{c}19(100 \%) \\
0(0 \%)\end{array}$ & $\begin{array}{c}0(0 \%) \\
69(100 \%)\end{array}$ & $\begin{array}{c}<0.0001 \\
(\mathrm{~S})\end{array}$ \\
\hline $\begin{array}{l}\text { Protein }(\mathrm{g} / \mathrm{dL}) \text { : } \\
<2.5 \\
>2.5\end{array}$ & $\begin{array}{c}8(42.1 \%) \\
11(57.9 \%)\end{array}$ & $\begin{array}{l}29(42.02 \%) \\
40(57.97 \%)\end{array}$ & $\begin{array}{l}0.99 \\
\text { (NS) }\end{array}$ \\
\hline $\begin{array}{l}\text { Glucose }(\mathrm{mg} / \mathrm{dL}) \text { : } \\
<140 \\
>140\end{array}$ & $\begin{array}{c}15(78.94 \%) \\
4(21 \%)\end{array}$ & $\begin{array}{l}18(26.08 \%) \\
51(73.91 \%)\end{array}$ & $\begin{array}{c}<0.0001 \\
(\mathrm{~S})\end{array}$ \\
\hline $\begin{array}{l}\text { PMNL cells/mm3: } \\
<250 \\
>250\end{array}$ & $\begin{array}{c}0(0 \%) \\
19(100 \%)\end{array}$ & $\begin{array}{c}69(100 \%) \\
0(0 \%)\end{array}$ & $\begin{array}{c}<0.0001 \\
(\mathrm{~S})\end{array}$ \\
\hline
\end{tabular}

Table (4): The distribution of pleural effusion in patients with uncomplicated hydrothorax and SBEM

\begin{tabular}{|c|c|c|c|c|c|}
\hline \multirow[t]{2}{*}{ Pleural effusion } & \multicolumn{2}{|c|}{$\operatorname{SBEM}(\mathbf{N}=19)$} & \multicolumn{2}{|c|}{$\begin{array}{c}\text { uncomplicated } \\
\text { hydrothorax } \\
(\mathbf{N}=81)\end{array}$} & \multirow[t]{2}{*}{ p-value } \\
\hline & No. & $\%$ & No. & $\%$ & \\
\hline $\begin{array}{l}\text { Bilateral pleural } \\
\text { effusion }\end{array}$ & 1 & 5.26 & 4 & 4.94 & \multirow{4}{*}{$\begin{array}{l}0.99 \\
\text { (NS) }\end{array}$} \\
\hline $\begin{array}{l}\text { LT Side pleural } \\
\text { effusion }\end{array}$ & 2 & 10.53 & 8 & 9.88 & \\
\hline $\begin{array}{l}\text { RT Side pleural } \\
\text { effusion }\end{array}$ & 16 & 84.21 & 69 & 85.19 & \\
\hline Total & 19 & 100 & 81 & 100 & \\
\hline
\end{tabular}

Table (5): Abdominal ultrasonographic findings in patients with SBEM and patients with uncomplicated hydrothorax

\begin{tabular}{|c|c|c|c|c|c|}
\hline \multirow{2}{*}{ Abd U.S } & \multicolumn{2}{|c|}{ SBEM } & \multicolumn{2}{|c|}{$\begin{array}{l}\text { uncomplicated } \\
\text { hydrothorax }\end{array}$} & \multirow{2}{*}{ p-value } \\
\hline & No. & $\%$ & No. & $\%$ & \\
\hline LC with ascites & 19 & 100 & 80 & 98.77 & \multirow{3}{*}{$\begin{array}{l}0.21 \\
(\mathrm{NS})\end{array}$} \\
\hline $\begin{array}{ll}\text { LC } & \text { without } \\
\text { ascites } & \\
\end{array}$ & $\mathbf{0}$ & $\mathbf{0}$ & 1 & 1.23 & \\
\hline Total & 19 & 100.00 & 81 & 100.00 & \\
\hline Associated SBP: & 10 & $(52.6 \%)$ & 6 & $7.4 \%$ & $\begin{array}{r}<.005 \\
(S)\end{array}$ \\
\hline
\end{tabular}




\section{DISCUSSION}

In the absence of cardiac or pulmonary disease, the presence of a pleural effusion in a cirrhotic patient is known as hepatic hydrothorax ${ }^{[11]}$. SBEM is the infection of a pre-existing hydrothorax in which pneumonia has been excluded. It has been reported to be present in 10\%-20\% of hospitalized patients with hepatic hydrothorax. Comparable to spontaneous bacterial peritonitis (SBP), SBEM is associated with a deteriorating prognosis with an estimated mortality rate over $20 \%^{[12]}$.

The current study disclosed some important observations. First, hepatic hydrothorax is a relatively uncommon complication in cirrhotic patients of 800 patients with liver cirrhosis, only 100 patients had hepatic hydrothorax with prevalence of $12.5 \%$. this result agreed with Chen et al. ${ }^{[3]}$ who reported $15 \%$ prevalence of pleural effusion, while Makhlouf et al. ${ }^{[13]}$ reported lower prevalence of hepatic hydrothorax $(6.8 \%)$ than our result. Second, SBEM is a rare complication of liver cirrhosis, but a more frequent $(19 \%)$ complication of cirrhotic patients with hydrothorax than in previous reports.

In the present study the frequency of SBEM among cirrhotic patients with hepatic hydrothorax was $19 \%$.This percentage is closely near to Xiol et $a l^{[3]}$ and Chen et $a l^{[4]}$ who reported that the incidence of SBEM was between $13 \%$ and $16 \%$, with a higher incidence in more advanced liver disease. However this result was less than that reported by Makhlouf et $a l^{[13]}$ who found that the prevalence was $26.2 \%$ and Gur et $a l^{[}$ ${ }^{4]}$ who also reported a higher prevalence reaching $30 \%$. The variation in incidence of spontaneous bacterial empyema in cirrhotic patients may be explained by the different diagnostic methods or the criteria for patient selection.

As regard development of pleural effusion (hepatic hydrothorax) in cirrhotic patients, we found that $1(1 \%)$ patients had hydrothorax without ascites, $84.21 \%$ of patients had right sided pleural effusion, $10.53 \%$ of patients had left sided pleural effusion and $5.26 \%$ of patients had bilateral pleural effusion. This result is agree with Mansour et $a l^{[13]}$ who reported that $85.8 \%$ of patients had right sided pleural effusion, $7.1 \%$ of patients had left sided pleural effusion and $7.1 \%$ of patients had bilateral pleural effusion. Chen et $a l^{[4]}$ showed that $4 \%$ of patients had hydrothorax without ascites and Makhlouf et $a l^{[13]}$ showed that $25 \%$ of patients had hydrothorax without ascites.

In the present study it was found that $52.6 \%$ of cirrhotic patients with spontaneous bacterial empyema had spontaneous bacterial peritonitis. Makhlouf et $a l^{[13]}$ reported that about $56.3 \%$ of patients had spontaneous bacterial peritonitis (SBP), also Chen $e t$ $a l^{[4]}$ reported that only $47 \%$ of patients had spontaneous bacterial peritonitis (SBP).

As regard pleural fluid examination in the present study, A high PMNL count was documented in all cases of SBEM, that PMNL count is the earliest and most reliable marker for SBEM. and our results are close to those reported by Xiol et al ${ }^{[3]}$.

\section{CONCLUSION}

SBEM was recognized in $19 \%$ of cirrhotic patients with ascites and hepatic hydrothorax. So, it is a frequent but underdiagnosed complication of hepatic hydrothorax and has a poor prognosis. More studies are required to elucidate the underlying pathogenetic mechanism and the natural course of SBEM. Meanwhile, its possible occurrence 
should be borne in mind in cases of hepatic hydrothorax who develop fever, encephalopathy or unexplained

\section{REFERENCES}

1. Emam M, Ibrahim A, Galal $S$, et al. (2015): Study of Frequency ofSpontaneous Bacterial Empyema in Cirrhotic Patients With Hepatic Hydrothorax. Journal of Gastroenterology and Hepatology Research; 4(4): 1569-1572.

2. Makhlouf HA, Morsy KH,Makhlouf NA,Eldin EN,Khairy M (2013): Spontaneous bacterial empyema in patients with liver cirrhosis in Upper Egypt: prevalence and causative organisms. Hepatolint; 7: 274-279.

3. Garcia N Jr, Mihas AA. Hepatic hydrothorax: pathophysiology, diagnosis and management. J Clin Gastroenterol 2004;38:52-58.

4. Xiol X, Castellvi JM, Guardiola J, et al. Spontaneous bacterial empyema in cirrhotic patients: a prospective study. Hepatology 1996;23:719-723.

5. Gur C, Ilan Y, Shibolet O. Hepatic hydrothorax-pathophysiology, diagnosis and treatment: review of the literature. Liver Int 2004;24:281-284.

6. Roussos A, Philippou N, Mantzaris GJ, Gourgouliannis KI. Hepatic

7. Cardenas A, Kelleher T, Chopra S. Review article: hepatic hydrothorax. Aliment Pharmacol Ther 2004;20:271279.

8. Chen C-H, Shih C-M, Chou J-W, et al. Outcome predictors of cirrhotic patients with spontaneous bacterial empyema. Liver Int 2011;31:417-424.

9. Allam NAH. Spontaneous bacterial empyema in liver cirrhosis: an underdiagnosed pleural complication. Saudi J Gastroenterol 2008; 14:43-45. deterioration of renal functions, particularly if they have high Child-Pugh score with or even without SBP.

hydrothorax: pathophysiology, diagnosis and management. J Gastroenterol Hepatol 2007;22:1388 1393.

10. Xiol X, Castellote J, Baliellas C, et al. Spontaneous bacterial empyema in cirrhotic patients: analysis of eleven cases. Hepatology 1990;11:365-370.

11. Andreu M, Sola R, Sitges-Serra A, et al. Risk factors for spontaneous bacterial peritonitis in cirrhotic patients with ascites. Gastroenterology 1993;104:1133-1138.

12. Lazaridis KN, Frank JW, Krowka MJ, Kamath PS. Hepatic hydrothorax: pathogenesis, diagnosis, and management. Am J Med 1999;107:262267.

13. Xiol X, Guardiola J. Hepatic hydrothorax. Curr Opin Pulm Med 1998;4:239-242.

14. Kinasewitz GT, Keddissi JI. Hepatic hydrothorax. Curr Opin Pulm Med 2003;9:261-265.

15. Chen T-A, Lo G-H, Lai K-H. Risk factors for spontaneous bacterial empyema in cirrhotic patients with hydrothorax. J Chin Med Assoc 2003;66:579-585.

16. Flaum MA. Spontaneous bacterial empyema in cirrhosis. Gastroenterology 1976;70:416-417.

17. Garcia Tsao G. Spontaneous bacterial peritonitis. Gastroenterol Clin North Am 1992;21:257-275.

18. Wyke RJ. Bacterial infections complicating liver disease. Baillieres Clin Gastroenterol 1989;3:187-210.

19. Sese E, Xiol $X$, Castellote J, Rodriguez-Farinas E, Tremosa G. Low complement levels and opsonic activity in hepatic hydrothorax: its relationship 
with spontaneous bacterial empyema. J Clin Gastroenterol 2003;36:75-77.

20. Felisart J, Rimola A, Arroyo V. Cefotaxime is more effective than is ampicillin-tobramycin in cirrhotics with severe infections. Hepatology 1985;5:457-462.

21. Runyon BA, Greenblatt M, Ming HC (1986) Hepatic hydrothorax treated for bacterial peritonitis. Dig Dis Sci 1991;36:1782-1786. 